\title{
Practice Research on English Reading Teaching Based on Picture Story Books in Primary School
}

\author{
Feng $\mathrm{He}$ \\ Feixian Campus, Linyi University, Linyi, Shandong, China \\ wangyinuo_2007@163.com
}

Keywords: English reading; Picture story books; Teaching practice

\begin{abstract}
Primary school English establishes an important stage for the students' English foundation. In recent years, with the continuous deepening development of education reform in our country, English curriculum in primary schools appeared a variety of innovative education contents and methods during the current period. English reading based on picture story books in primary schools is such kind of the new form, including vivid and interesting contents, as well as the musical characteristics, which is popular with the students. It is of great significance and value to the development of teaching. This paper analyzes the practice teaching of English reading based on picture story books in primary schools, and hopes to provide some useful help and suggestions for English teaching in primary schools.
\end{abstract}

\section{Introduction}

Picture story book is a kind of literary works with plot and pictures, which is suitable for primary school students. At present, picture story book has become a popular way for teachers to apply in the teaching practice, but there are still some problems in the teaching practice, and the real utility of picture story books hasn't been grasped. Therefore, the analysis of reading teaching based on picture story books must be actively exerted in the current stage in primary schools, so as to find a more effective way to carry out practical teaching and contribute to the development of primary English. This paper will give a detailed discussion to the teaching practice of English reading based on picture story books in primary schools.

\section{Connotation of Picture Story Books}

Picture story books are similar to traditional comic books, which are also called picture books. In recent years, due to the rapid development of the market economics, the use of picture story books has become an important education method used in the current educational field. Picture story book is a kind of picture book, which contains not only pictures, but the use of pictures to convey more valuable contents and knowledge, and the picture is a kind of important expression. The pictures not only annotate the words, but also enrich and strengthen the text further. Picture story books, appearing as the form of story books, show the value and justification implied in the story through the form of picture books to the readers, and have also become important parts of social development and cultural inheritance.

From this we can see that the picture story book is a way to use pictures to tell the story, so that readers can understand the meaning and the justification in the story. Therefore, it can be said that firstly, picture story book is a book, even if it has only a few pages, which contains a complete story, and a book implying some truth. There are certain restrictive factors for children to read the text, but due to their better development of image thinking, the form of pictures are more likely to draw their attention, and can also have important significance for their further development in thinking. The way of reading teaching based on picture story books can cause primary school student's mental development, promote their perceptual skill training, so that they can understand society in a more correct view and contribute to the development of human civilization. 


\section{Significance of English Reading Based on Picture Story Books}

The author will integrate his feelings and thoughts into his English picture story book, and then express them in words and images, which is more vivid. For example, in The Giving Tree, the author do some phrases reading. This reading coordinate pictures with simple black lines, which is in combination with black and white color. In this way, the reader can feel the delicate and warm feeling in the simple image. The article has repeatedly emphasized that "... and the tree was happy". This kind of repeated mention also has a certain emotional significance, let the students express themselves with different tones according to their own understanding, and form a picture belonging to themselves through the combination of images and the statements in mind. In this way, students can integrate pictures and story plots into further analysis when they encounter words or sentences they don't understand, and get corresponding solutions.

Picture story books itself has a variety of different status, from the angle of the development of the students, picture story books we used in English reading are basically scientific picture story books, which mainly contains reading, understanding, and the master of language, guiding students to promote their English knowledge, and at the same time, further improve their comprehensive quality. From its classification, English story picture books can improve students' language ability by telling stories, make students get the cultivation of reasoning ability and communication skills by the way of reasoning, as well as the mental development through the reading of English picture story books, especially the ability of observation and understanding will be effectively promoted. This will play an important role in the future development of primary school students and the cultivation of core quality.

\section{Countermeasure in English Reading Teaching Based on Picture Story Books}

Reasonable Selection of English Picture Story Books. In the selection of picture story books, teachers need to take comprehensive consideration from many aspects. Because younger children have poorly understanding ability, English teachers should try to choose picture story books which are short, fast-paced, and low structural difficulty in sentences. For example, in Elfabet, through the combination of lovely elves and letters, the author draw the outline with warm colors and made the letters associate with the thinking of the whole story, which let the letters become an independent image. In the teaching of picture story books for senior students, teachers should try to choose some expansive contents which are more suitable for them.

But teachers should pay attention that in the whole learning process, they must make targeted edition to the original sentences to change the new words into a kind of commonly used words. The unification of tenses can also facilitate students' understanding. This kind of edition can also divide the picture story books with traditional books teaching thoroughly to reduce students fear in their heart, which makes them apply themselves to the study of the English picture story books with great willingness and energy, which lead to better learning effects.

At the same time, teachers should pay attention to the children's interest in the selection of English picture story books. The development of primary school students' thinking is not perfect, and has the very strong tendency of children's interest. Therefore English teachers must have new ideas to choose some picture story books which have new meanings and can make people laugh, so as to attract the students to actively participate in the English reading teaching.

Now there are a lot of different kinds of English picture story books. Teachers need to select the reading materials based on the comprehensive analysis of students' interests, characters and hobbies to let students integrate into picture story books. For example, in Mr Pig Has A Picnic, the plot focuses on Mr Pig who wants to invite Miss pig to go out for a picnic. In order to make himself look more handsome, Mr Pig borrowed the best parts of his good friends, such as lions, zebras, and foxes to dress up himself, which lead to the result of him becoming an ugly monster. The story is so much fun that students are more likely to accept it, stimulates students enthusiasm for picture story books and continuous reading, which provides guarantee for the reading effects.

In addition, it is necessary to select picture story books with more repetitious language. The 
picture story books which are chosen can't be too difficult. Because of the poor understanding of primary school students, if the language difficulty in the picture story book is above their level, the students will have the learning obstacle, which leads to the loss of interest in the picture story book. Therefore, in order to achieve good results, teachers need to choose those with simple and easy to understand contents as the teaching material of picture story book. Like the story of Mr Pig, this sentence pattern, "Can I use your... " repeatedly appear in it, and students will see it repeatedly in the process of reading, which will have an important significance for their understanding ability and future practical application. In addition, in the teaching process, recurring language will decrease the difficulty of learning and can make students get a boost in the osmosis rather than mechanic memorization, and therefore students are more likely to feel the fun of learning.

Guidance of Picture Story Books Reading. In the reading guidance of picture story books, firstly, teachers can make students observe the cover of the picture story book. Through the observation of the cover, students try to imagine what kind of story it is. For example, when reading Guess How Much I Love You, you can see that the mother rabbit's love for the baby rabbit. Then after the observation of the cover, students express the story combining with the pictures. Or the teacher can tell the dialogue to the students in the form of story, so that the students can have a more clearly understanding to the true feelings contained in the story. After the reading of the picture book, the teacher should guide the students to further analyze the pictures and sentences in the book to help them gain more knowledge from it. Rich pictures can help students to get visual relief in the process of learning, expand their thinking and imagination, and integrate the tense learned in this class into vivid pictures.

Teachers should also pay attention to leaving a certain amount of time for students to imagine after reading. Because picture story books itself have relatively strong artistic quality, if the teachers can leave some space for students to imagine, students can have fully divergent thinking in the limited time and space, arouse their enthusiasm and achieve the goal of expanding horizons by means of picture story books.

Effective Reading of Picture Story Books. The process of reading is of great importance to the promotion of reading effect. The key of the current curriculum for teachers lies in how to grasp the essence in the process of reading. Only after grasping of the key points can students improve their reading effects. For example, in the explanation of The Three Goats, the teacher takes the method of the preparation in the pre-reading - the expansion and the display in the mid-reading - the extension in the after-reading to carry out the teaching, so that the students can gradually be integrated into the picture story book. In the early stage of the reading process, the teacher should clear this task. The teacher imitates goat's walking posture, and leads representative figure by way of onomatopoeia. "Tippity-tap. Tippity-tap. Here comes a Baby goat/Sister goat/Brother goat." "Rumble, Tumble. Rumble, Tumble. Here comes Ugly Bogy." Teachers can behave more exaggeratedly, and then let the students feel the characteristics of the characters. Through this kind of guidance, students can quickly integrate into it.

Then the teacher should make a further reading and understanding of the picture story book. The teacher can make the teaching arrangement by way of the story performance, so that the students can gradually enter the teaching scene set by the teacher. Students are more motivated into the story because they can participate directly in it. In this way, students can get further exercise in thinking and make the story more completely, which can also make students' memories more profoundly.

Analysis of Teaching Effects of Picture Story Books. In the English reading teaching of picture story books, students' enthusiasm and learning interest are obviously improved, and they also show a certain English ability. However, because there are some problems in the picture story books, students are still be affected. Therefore, after teaching, teachers should make further analysis to the effect of teaching and know which part of the students is hindered. According to the actual situation of students, the teacher should carry on the further selection of picture story books to ensure the science of the English reading teaching based on picture story books. In addition, after reading, the teacher should actively collect the students' suggestions to ensure that students' subjectivity can be played and they feel the emotional power in reading and get emotional sublimation. Only when 
teachers understand the practical teaching effect of picture story books can teachers make positive adjustment in the future teaching and improve the effect of English reading based on picture story books.

Reading based on picture story books has been widely used at present due to its short and flexible features. Applying English picture story books into daily teaching can make English class further rich, can also let students feel the fun of learning English, which is an important measure to improve the teaching quality and effects. The development of practice application of English picture story books in the current stage in our country is still in its infancy, with lots of deficiencies. As a result, teachers also need to dig English picture story books further to the application of English reading teaching practice to make them play a better role.

\section{References}

[1] He Fang, Four Keys to English Reading Based on Picture Books in Primary School, China Education Technical Equipment. 2015(3):210-231.

[2] Liu Xijia, Using English Picture Books to Carry Out Reading Teaching, Spiritual Leaders, 2015(12):77-80.

[3] Jiang MeiLi, A Brief Analysis of the Application of English Picture Books in Primary English Teaching, Asia-pacific Education, 2015(21):54-63.

[4] Ye Yiqing, Exploration of English Picture Books in Primary School English Teaching, Overseas English, 2013(8):88-93. 